\title{
The Predicament and Countermeasure of Legal Literacy Cultivation of College Students in China
}

\author{
Wu Liansong ${ }^{1}$, Liu Honglian ${ }^{2}$ \\ ${ }^{1}$ School of International Education, Yangtze University, Jingzhou, China \\ ${ }^{2}$ Jingzhou Experimental Middle School, Jingzhou, China
}

Email address:

wls@mails.ccnu.edu.cn (Wu Liansong), 415403044@qq.com (Liu Honglian)

To cite this article:

Wu Liansong, Liu Honglian. The Predicament and Countermeasure of Legal Literacy Cultivation of College Students in China. International Journal of Education, Culture and Society. Vol. 3, No. 1, 2018, pp. 1-4. doi: 10.11648/j.ijecs.20180301.11

Received: November 13, 2017; Accepted: November 21, 2017; Published: January 2, 2018

\begin{abstract}
College students are the important body of ruling by law. Strengthening the legal education and improving the legal literacy of college students are not only the important content of ruling by law but also an important subject of ideological and political education in Chinese colleges. At present, the negative factors of social development are not conducive to the cultivation of college students' legal literacy. The lack of legal education in colleges restricts the improvement of legal literacy of college students and the weak legal consciousness influences the cultivation of legal literacy. It is helpful to improve the legal literacy level of college students by fully implementing the law-based governance of colleges, optimizing legal education in colleges and strengthening the legal beliefs of college students in accordance with the principle of ruling by law.
\end{abstract}

Keywords: Predicament, Countermeasure, Legal, Literacy, College Students

\section{Introduction}

The Fourth Plenary Session of the Eighteenth Central Committee of the Communist Party of China puts forward that "we must carry forward the socialist spirits of rule of law and build a socialist culture of rule by law ", it also stresses that we should promote the whole society to establish the consciousness of rule by law, deepen the publicity of the education of rule of law, meanwhile integrate the education of rule of law into the national education system and the content of spiritual civilization. [1] College students are valuable human resources, the hope and the future of our nation, whose legal literacy level is closely related to the construction of the rule of law. With the diversification of the world gradually deepening, diverse values continue to impact thoughts of college students, affecting their value selection and judgment. Under the background of diverse values, it is necessary to construct the rule of law in China and enhance the ability of modern social governance.

\section{The Main Content of College Student's Legal Literacy}

"The legal literacy as well as the moral cultivation, now increasingly becomes an important standard in assessing the quality of the nation." On a book named "Outline on quality education of secondary schools and primary schools in the 21 st century", "literacy" is defined as "what people acquired on the basis of innate physiology through environmental impact and education training is the inherent, relatively stable, long-term effective physical and mental characteristics and basic quality." Thus, the quality is not innate, but a multi-level knowledge and consciousness system established by people's internalizing and integrating the knowledge obtained by learning in daily life, which is a kind of values as well as a way of life.

Marx once pointed out, "For law, I do not exist except for my actions. I am not law at all. My behavior is the only field where I deal with the law." [2] Legal literacy mainly refers to the ability and quality of people to deal with affairs or accidents with the law. [3] A person's legal literacy is manifested through its legal consciousness and the ability to master the usage of legal knowledge. Legal literacy of college students is to master certain legal knowledge, build up the recognition of law, establish legal belief, and consciously use the law to regulate their own behaviors and the abilities to deal with various social relations. This concept includes three aspects: the first is the grasp of legislative principles and legal 
knowledge, the second is the formation of legal beliefs and consciousness, and the third is to see whether the behavior is in line with legal norms.

\section{The Current Difficulties Faced by Chinese College Students in Legal Literacy}

In recent years, with the continuous advancement of the strategy of ruling by law, the legal awareness of college students has been strengthened and the attention to national law has increased. The overall understanding of the law is healthy and the legal literacy of college students has been improved. However, influenced by the social, school and college students themselves and many other subjective and objective factors, the current legal literacy of college students still faces many difficulties.

\subsection{Negative Factors of Social Development Are Not Conducive to the Cultivation of College Students' Legal Literacy}

For a long time, many people only regard the law as a tool, ignoring such core values the law itself pursuits as freedom, equality and justice. In order to win more attention, various media often like to report cases of social injustice in detail. And increasingly reports of negative information make the "positive energy" of the whole society less and less, which makes college students doubt about the law. At the same time, when the development of market economy brings the rich material to the masse, some negative effects emerge, such as unfair distribution of benefits, corruption and other phenomena continuously devour college students' trust towards law which originally is little. "In the era of competing family background and relations, college students' psychological imbalance is unavoidable. And their not yet fully mature minds are difficult to resist money worship, hedonism and the erosion of other decadent ideas. Therefore they are easily to lose themselves and even lose mind to do things at the expense of the law. [4] These social negative factors make the law difficult to be trusted, coupled with the phenomenon that law has not been obeyed and the emergence of judicial injustice. The idea of legal nihilism in the college students also have the momentum to spread and negative sense of loss greatly restricted college students on their initiative to learn, use and abide by law.

\subsection{The Lack of Legal Education in Colleges and Universities Limits the Promotion of College Students' Legal Literacy}

At present, the legal education of colleges is to cultivate the legal awareness of college students and make them master the basic legal knowledge, mainly including the basic theory of law, basic legal knowledge and legal concept education. "Ideological and moral cultivation and legal basis" is a legal channel for non - legal professional college students to accept legal education. The lack of legal education in colleges limits the improvement of legal literacy of college students in the following aspects: Firstly, although the textbook is rich in content and the system is also very strong, the theory is very obscure and there are few cases can interest college students, making it hard for college students to understand its essence. Secondly, the class time is limited whereas the content is complex. Professors teach things superficially and rush to get them finished, all they do is to list a series of knowledge and accumulations. In that case, students are often struggling to cope with and memorize mechanically to pass the exam. Due to the fact that teachers impart knowledge in a classroom with many students, the effect is difficult to guarantee. The third is that teachers who undertake tasks such as political science, Marxist theory and other disciplines are those who teach ideological and political classes. Due to the lack of professional legal knowledge, they cannot comprehend the course deeply, so it is difficult for them to make in-depth analysis and combine them with the actual needs of students.

\subsection{The Weak Legal Awareness of College Students Affects the Cultivation of Legal Literacy}

The psychological and physiological characteristics of college students determine the practicability, immaturity and instability of their legal consciousness and legal behavior. The environment they are in is relatively simple and their characters are relatively strong and extremely. Many college students are fragile and ill to afford setbacks. Besides, they are emotional, blindfolded and easy to impulse, and their vigilance is not high. Many of them only pay attention to their own professional learning without mastering the basic knowledge of the law and the ability to use the law, thus unable to form the correct legal awareness. With more cases breaching the law in the community enlarged by the bad media, college students have strong sense of resistance to social injustice and powerless feeling willing up them, which causes college students a psychological confusion to the law and a lack of confidence in the law. Due to the fact that all these problems haven't been solved for a long time, they become gloomy, melancholy, confused, disappointed, anger, panic, etc. All emotional accumulations will make the students feel that there is no need for them to cultivate their own legal literacy.

"College students lack social life experience, and their ideas are relatively simple. What's more, their legal consciousness is relatively weak" [5], mainly shown in the following two aspects: Firstly, they don't form the correct equal view of rights and obligations, lack awareness of rights and fail to realize the protection of civil rights. Secondly, they lack legal knowledge and a solid legal knowledge, thinking that understand a little knowledge is equal to master law. Because they don't know the law, nor understand the law, resulting their deviated legal awareness, which is bound to affect college students how to choose their behaviors. With legal literacy of college students gradually weakening, the cases of Ma Jiajue, Yao Jiaxin, Lin Senhao and other college students can show this phenomenon when they commit crimes. 


\section{The Practical Measures to Enhance the Legal Literacy of College Students Under the Background of the Rule by Law}

"CPC Central Committee on promoting a number of major issues of governing the country according to law" was passed at the Fourth Plenary Session of the 18th CPC Central Committee. It is a strategic plan for the administration of the Chinese Communist Party under the new situation, which depicts the grand blueprint to construct a state of the rule by law. In the future, we will promote the construction of the rule of law society and strengthen the basic guide of the concept of all citizens to adhere to rule by law. It is also the general requirement to strengthen the education of the rule by law and enhance the legal literacy of college students.

\subsection{Fully Implement the Rule by Law}

The Fourth Plenary Session of the Eighteenth Central Committee of the Communist Party of China has fully deployed the general goal of ruling by law, which is to build a socialist country with rule by law, strengthen the legal education of college students and promote the legal literacy of college students, requiring that college students should be guided to grasp the profound understanding of the connotation of the socialist system of rule by law with Chinese characteristics. Besides, we must adhere to the leadership of the Communist Party of China, the people-centered policy and the fact that all people are equal before the law. What's more, we should adhere to ruling by law and ruling by virtue and adhere to starting from the actual and present facts of China. This is the overall goal which we must obey to strengthen the legal education of college students and enhance the legal literacy of college students.

Based on democracy, managing schools according to the law is to comply with the provisions of the Constitution and the law, especially the provisions of education laws and regulations, using legal means, economic means, administrative means to manage and govern schools to make sure the implementation of the schools' all kinds of assignments become legalization and standardization. China's Ministry of Education issued in 2003, " a number of opinions on strengthening the work to govern schools with rule by law " and " the outline to comprehensively promote the implementation of rule by law " in 2013, both of which have stated that " managing schools according to the law is an important part of governing the state with rule by law and the former is the implementation of the latter. To govern schools with the law is to use legal means to standardize the behavior of teachers and students, as well as the inherent requirements of modern university management. "[6] Only by adhering to the rule by law, a healthy atmosphere of law can be created in the campus and thus an excellent campus culture can be made. Colleges and universities should follow the laws and regulations and the school constitution management to make accurate use of legal means to implement the school management, which is the important external conditions to cultivate the legal quality of college students.

\subsection{Optimize the Legal Education in Colleges and Universities}

The key to strengthen the legal literacy of college students is to focus on education while the key to strengthen the construction of the legal system is to cultivate college students' legal literacy. For now, the main channel of Chinese college students' legal education is the class of "ideological and moral cultivation and legal basis". It plays a role that cannot be replaced by other courses in terms of popularizing legal knowledge, cultivating and improving the socialist legal opinions and legal consciousness of college students. Therefore, in the process of cultivating college students' legal literacy, we must rely on this course and regard it as the main position of college students' legal literacy training.

First, strengthen the construction of teachers' legal education. To establish a team of teachers with high professional quality, high sense of team, reasonable structure and professional legal knowledge and high legal literacy is the inherent requirement for cultivating college students' legal literacy. Colleges and universities should organize the course for teachers to focus on learning legal knowledge and invite legal experts and education experts to give lectures to ensure that every teacher can know the law, abide by the law, use law and form their legal awareness, as a whole to enhance the legal quality of teachers. Second, the class time of legal courses should be increased rationally. It is one of the most important means to increase the effectiveness of cultivating college students' legal literacy by rationally increasing the time of courses of law. This will enable teachers to arrange classes more scientifically and enable students to have more time to study the law and improve the quality of the class. In some advanced schools, adding optional legal courses to expand the legal vision of college students will also be reasonable. The third is to increase the entity platform with high operability. "Legal education is a very practical course, requiring students to experience and participate in themselves." [7] At present, many schools regard the moot court as an important platform to enhance the legal literacy of college students. Colleges and universities should not only be equipped with professional instructors but also make it a fixed place to do practice with rule by law. The establishment of standardized moot courts is the necessary condition for college students to carry out legal practice.

\subsection{Firm Legal Beliefs of College Students}

"The legal belief is the highest level of the goal of legal education and the realization of the rule by law requires good soil of rule by law and people's recognition. As the hope of our national revival, our college students' faith will directly affect the rise and fall of China's rule by law [8]. We should be firm to believe freedom, equality, justice and other spirits of the rule by law and believe in the positive energy of the law, and firmly believe that the law can effectively protect the 
legitimate rights and interests of citizens and punish the criminal acts in order to arouse the students' enthusiasm for learning, abiding by and protecting law, thus developing a good way to think the rule by law. China's long-term "the rule by man " thought makes people often believe that power is more important than the law and many people have been indifferent to their legal belief in heart. To enhance the university's legal literacy and build a rule by law society, we must strengthen the legal beliefs of college students.

On the one hand, we should optimize the social environment. "Good legal environment is conducive to promote the development of rule by law and enhance the rule by law consciousness." [9] Implementing law and justice law stably and lastingly not only will make students have a sense of affinity but also develop the fixed mindset to rely on and worship law on this basis, then escalating into a sense of identity and a sense of belonging, which are the important prerequisites to make college students have firm legal beliefs. With the rapid development of democracy and legal system in our country in recent years, especially the strategic decision of "governing the country according to law and building a socialist country ruled by law", there has been a great change from political society to legal state in our country. This provides a better environment for the implementation of legal literacy education. On the other hand, college students should consciously learn the law, observe the law and protect the law. College students should form the concept that breaching law is shameful and law-abiding is honorable [10] College students should study what is closely related to the law, figuring out what can be done, what cannot be done, what is allowed by law, what is prohibited by law, and do a model of law-abiding. Apart from that, we also should protect law. College students should consciously cultivate legal thinking. When confronted with reasonably lawless or unfair circumstances, we should comply with the law, protect the law, trust law and consciously safeguard the authority of the law.

\section{Conclusion}

In short, college students are the builders and successors of our nation, but also an important role in governing states with the law. The legal literacy of college students not only plays an important role in their own cultivating structure but also occupies a more critical position in the cultivation of whole citizenship. Cultivating and improving the legal literacy of college students can not only promote the improvement of the whole national quality but also speed up the perfection of Chinese legal system and presume the process of the rule by law in China.

\section{References}

[1] 18th Plenary Session of the Eighth Central Committee of the Communist Party of China through the rule of law on a number of major issues decided to publish the bulletin[EB/OL].www.guancha.cn / politics / 2014_10_23_279026.shtml.2014-10-23.

[2] Selected Works of Marx and Engels, Volume 1, Beijing: People's Publishing House, 1995: 121.

[3] Di Shuang, Fu Weitao. Under the new situation of China's college students legal status and analysis of countermeasures. [J]. Shandong Social Sciences, 2015 (s1): 23-24.

[4] Zhang Kang. Study on strengthening researches of legal education in college students' Ideological and political education. [J]. Journal of Hubei University of Economics (HUMANITIES AND SOCIAL SCIENCES EDITION), 2014 (3): 141-142.

[5] Zhang Pan. On raising some thoughts of the legal literacy of college students. [J]. School Party Building and Ideological Education, 2016 (10): 45-47.

[6] Notice of Ministry of education on Issuing the outline of "comprehensively promoting the implementation of school by law" ([EB/OL].

http://old.moe.gov.cn//publicfiles/business/htmlfiles/moe/s593 3/201301/146831.html.)

[7] Fang Fang. The cultivation and the improvement of Youth Legal Status. [J]. Tianjin Medical Journal, 2017 (2): 37-39.

[8] Zhang Dafang and Qin Jianhui. Construction of College Students' Cultivation of legal faith system [J]. Expo 2014 Kan, (2).

[9] Deng Qiaorong. Analysis on the cultivation of College Students' thinking on rule of law.[J]. School Party Building and Ideological Education, 2017 (7): 64-66.

[10] Li Weigang. How to cultivate students' rule of law thinking.[J]. Legal System and Society, 2017 (4): 240-241. 